\title{
Glosa do wyroku Sądu Apelacyjnego w Białymstoku z dnia 21 stycznia 2014 r. III AUa 813/13
}

1.

Teza: „Przycięcie krzewów do kształtu kuli i stożka nie sposób zakwalifikować jak wykonanie umowy o dzieło".

2.

Stan faktyczny, będący podstawą wydania glosowanego orzeczenia ${ }^{1}$, był bezsporny. Przedmiotem zawartej przez strony umowy o dzieło było formowanie bukszpanów (około 200 sztuk) i tui (ponad 10 sztuk). Zakład Ubezpieczeń Społecznych uznał, że zawarta przez strony umowa nie jest umową o dzieło, a umową o świadczenie usług, która podlega „oskładkowaniu”.

\footnotetext{
$1 \quad$ LEX nr 1422316.
} 
Rozpatrując odwołanie od decyzji ZUS, Sąd Okręgowy w Białymstoku w wyroku z dnia 29 kwietnia 2013 r. $^{2}$ uznał, że kwestionowaną przez ZUS umowę zawartą dnia 2 maja 2009 r. należy uznać za umowę o dzieło. Sąd wskazał, że dokonując analizy charakteru łączącej strony umowy, miał na uwadze cel i zgodny zamiar stron. SO uznał, że przeprowadzone z sprawie postępowanie dowodowe wykazało, że rzeczywistą wolą stron było zawarcie umowy o dzieło, gdyż celem podjętych czynności było osiągnięcie konkretnego rezultatu, który podlegał ocenie (odbiorowi) pod kątem istnienia ewentualnych wad. Nie była to zatem umowa starannego działania.

\section{3.}

Sąd Apelacyjny uznał wyrok SO za błędny. Niestety, przygotowane przez SA uzasadnienie prawne nie pozwala na to, by podzielić stanowisko sądu II instancji. Teza i motywy komentowanego wyroku są nieprzekonujące i niedostatecznie uzasadnione.

Istota sporu sprowadza się ,jedynie” do tego, czy umowa dotycząca przecięcia krzewów do określonego kształtu to umowa o dzieło czy umowa o świadczenie usług. Mając na uwadze, że sądy obu instancji orzekały w zakresie prawidłowości decyzji wydanej przez ZUS, trzeba podkreślić, że dla obowiązku „oskładkowania” (bądź jego braku) przychodów z zawartej umowy istotna jest interpretacja art. 627 k.c. ${ }^{3}$ Tymczasem SA w Białymstoku uzasadnienie prawne oparł na lakonicznej wykładni wybranych przepisów Kodeksu cywilnego i wybranych orzeczeniach. Dobór przywołanych wyroków sprawia wrażenie przypadkowego. Zwraca uwagę, że spośród powołanych 3 wyroków Sądu Najwyższego tylko jeden został wydany przez Izbę Cywilną. Z kolei wszystkie trzy orzeczenia Sądów Apelacyjnych zostały wydane w sprawach ubezpieczeniowych, a nie cywilnych. Ponadto - z niezrozumiałych powodów - SA w Białymstoku zupełnie pominął bogaty dorobek doktryny prawa cywilnego ${ }^{4}$.

\footnotetext{
V U 88/13, http://orzeczenia.bialystok.so.gov.pl.

Ustawa z dnia 23 kwietnia 1964 r. Kodeks cywilny (tekst jedn. Dz.U. z 2014 r., poz. 121).

Sąd lakonicznie stwierdził: „Przedmiotowa problematyka jest szeroko komentowana w literaturze prawniczej”, nie wskazał jednak żadnych konkretów.
} 


\section{4.}

Nieuzasadnione merytorycznie twierdzenie przez SA, że „Przycięcie krzewów do kształtu kuli i stożka nie sposób zakwalifikować jak wykonanie umowy o dzieło" nie jest, niestety, odosobnione w orzecznictwie sądów okręgowych i apelacyjnych orzekających w „sprawach składkowych”. Trudno zrozumieć, dlaczego w orzecznictwie kwestionuje się, że niektóre prace $\mathrm{w}$ rolnictwie, ogrodnictwie czy warzywnictwie mogą być wykonywane na podstawie umów o dzieło.

Na pierwszy rzut oka można przyjąć, że niekiedy granica między świadczeniem usług a wykonywaniem może być nieostra, jednakże w każdym wątpliwym przypadku można dokonać wszechstronnej oceny umowy i ją odpowiednio prawnie zakwalifikować. Niezależnie od typu umowy, w ramach każdej dłużnik powinien wykonywać czynności z zachowaniem należytej staranności, w ten sam sposób powinien współdziałać z nim wierzyciel (art. 354 k.c.). Jedynie zatem jednoznaczne stwierdzenie, że umowa zawarta między stronami nie jest umową, której przedmiotem jest osiągnięcie określonego przez strony rezultatu (zobowiązanie rezultatu), pozwalałoby na przyjęcie interpretacji pozwalającej na „oskładkowanie” tej czynności (zobowiązanie starannego działania).

W orzecznictwie wskazuje się, że „kryterium odróżnienia umowy o dzieło od umowy o świadczenie usług stanowi także możliwość poddania umówionego rezultatu (dzieła) sprawdzianowi na istnienie wad fizycznych $^{5}$. Nie ma wątpliwości, że możliwe jest poddanie sprawdzianowi na istnienie wad fizycznych rezultatu umowy, której przedmiotem jest zarówno przycięcie krzewów (drzew) do określonego kształtu, obranie i oczyszczenie cebuli, zebranie owoców spełniających wskazane kryteria z określonej powierzchni, opielenie i odchwaszczenie wskazanej działki etc. Co więcej, rezultat dzieła we wskazanych przykładach jest z góry określony ${ }^{6}$, co umożliwia jego weryfikację pod kątem zgodności z treścią zawartej umowy o dzieło.

\footnotetext{
Zob. wyrok SN z dnia 3 listopada 2000 r., IV CKN 152/00, LEX nr 45451.

Zob. wyrok SN z dnia 13 czerwca 2012 r., II UK 308/11, LEX nr 1235841.
} 
Słusznie zatem stwierdził Sąd Apelacyjny w Łodzi w wyroku z dnia 5 marca 2013 r. ${ }^{7}$, że gdy granica między usługami a dziełem jest płynna, to za kryterium odróżniające uznaje się możliwość poddania umówionego rezultatu dzieła sprawdzianowi na istnienie wad fizycznych ${ }^{8}$.

\section{5.}

W literaturze wskazuje się, że przedmiotem świadczenia przyjmującego zamówienie jest wykonanie dzieła, które może polegać na jego stworzeniu lub przetworzeniu do takiej postaci, w jakiej poprzednio nie istniało ${ }^{9}$. Charakter umów o dzieło mają również umowy zawierane przez rolników z jednostkami usługowymi o wykonanie takich prac polowych, jak: orka, siew, zebranie plonów lub wymłócenie ${ }^{10}$. Są to niewątpliwie umowy rezultatu. Nie chodzi w nich bowiem o dokonywanie czynności składających się na tego rodzaju prace polowe, ale o skuteczne ich wykonanie ${ }^{11}$. W przypadku krzewów przycięcie do kształtu wskazanego w umowie oznacza właśnie owo „przetworzenie” (podobnie jak w przypadku pozostałych wyżej wskazanych przykładów). Dodać należy, że przycięcie krzewów do określonego kształtu to wykonanie oznaczonego dzieła, będące procesem pracy o określonym momencie początkowym i końcowym. Celem tego procesu jest doprowadzenie do efektu (rezultatu) okre-

\footnotetext{
III AUa 851/12, LEX nr 1312047.

8 Tak też wyroki SN: z dnia 28 marca 2000 r., II UKN 386/99, OSNP 2001, nr 16 poz. 522; z dnia 3 listopada 2000 r., IV CKN 152/2000, OSNC 2001, nr 4 poz. 63; z dnia 9 maja 2007 r., II CSK 77/2007, Lexis.pl nr 1390795 i z dnia 9 grudnia 2008 r. I UK 140/2008, Lexis.pl nr 1996175.

9 A. Brzozowski [w:] K. Pietrzykowski (red.), Kodeks cywilny. Komentarz. Tom II, Warszawa 2011, s. 411; tak również: G. Kozieł [w:] A. Kidyba (red.), Kodeks cywilny. Komentarz. Tom III. Zobowiq̨zania - część szczególna, Warszawa 2010, s. 232; zob. też wyrok SN z 18 września 2013 r., II UK 39/13, Lexis.pl nr 7537975 - wykonanie umowy przez zainteresowanego polegało na zagruntowaniu, wyszpachlowaniu i pomalowaniu pomieszczeń biurowych przy użyciu materiałów dostarczonych przez zamawiającego.

10 Zob. wyrok SN z dnia 22 czerwca 1976 r., II CR 193/76, OSPiKA 1976, nr 11-12, poz. 194.

11 Zob. K. Kołakowski, Komentarz do art. 627 [w:] G. Bieniek (red.), Komentarz do kodeksu cywilnego. Księga trzecia. Zobowiq̨zania, tom 1, Warszawa 2011, Lexis.pl (elektr.).
} 
ślonego przez strony w umowie, przy czym stopień tego określenia może mieć różny stopień dokładności ${ }^{12}$.

Niewątpliwie umowa o dzieło różni się od umowy o świadczenie usług tym, że zawsze musi być uwieńczona konkretnym i sprawdzalnym rezultatem; mniejsze znaczenie ma obowiązek osobistego wykonania dzieła (chyba że w umowie postanowiono inaczej), ważne by osiągnięty został rezultat końcowy ${ }^{13}$. W zakresie umów, będących przedmiotem rozważań SA, nie ma wątpliwości, że chodziło o osiągnięcie efektu w postaci określonego kształtu krzewów.

\section{6.}

Trudno zgodzić się ze stwierdzeniem sądu, że „Oczywiście popularność umowy o dzieło wynika z faktu, że z tytułu zawarcia takiej umowy nie powstaje obowiązek ubezpieczenia społecznego”. Nie wiadomo, na jakich badaniach sąd oparł takie stanowisko. Przede wszystkim zawierane umowy (w tym: o dzieło) rodzą skutki cywilnoprawne pomiędzy jej stronami. W związku z tym strony zawierają takie umowy, które są dla nich korzystne. Jest to naturalna konsekwencja funkcjonowania gospodarki wolnorynkowej. Dodać należy, że zgodnie z art. $353^{1}$ Kodeksu cywilnego strony zawierające umowę mogą ułożyć stosunek prawny według swego uznania, byleby treść lub cel nie sprzeciwiały się właściwości (naturze) stosunku, ustawie ani zasadom współżycia społecznego.

Zawierane umowy rodzą oczywiście także konsekwencje na gruncie publicznoprawnym, zwłaszcza w zakresie prawa daninowego (podatki, składki). Trudno zgodzić się ze stanowiskiem sądu, że „popularność umowy o dzieło” wynika z braku obowiązków w zakresie ubezpieczeń społecznych, nie można bowiem zapominać, że np. umowy o dzieło i umowy o świadczenie usług - w zakresie obciążeń podatkowych - nie są traktowane przez ustawodawcę identycznie. Zawierając umowę o dzieło, strony mogę mieć na uwadze (poza skutkami cywilnoprawnymi) głównie

12 A. Brzozowski, Kodeks cywilny. Komentarz..., s. 411.

13 Tamże, s. 414. 
np. koszty uzyskania przychodu, a kwestii podlegania ubezpieczeniom społecznym nie brać pod uwagę. Dla SA orzekającego w przedmiotowej sprawie powinno być istotne, że w przypadku wielu umów problem podlegania ubezpieczeniom w praktyce nie istnieje - składka emerytalna i składki rentowe nie są pobierane $\mathrm{w}$ danym roku od nadwyżki ponad kwotę „ograniczenia” (trzydziestokrotność prognozowanego przeciętnego miesięcznego wynagrodzenia). Natomiast w zakresie podatku dochodowego od osób fizycznych - wobec istnienia progresywnej skali opodatkowania - 50-procentowe koszty uzyskania przychodu z umów o dzieło realnie obniżają obciążenia podatkowe podatnika. Doszukiwanie się zatem motywacji stron umowy co do wyboru umowy o dzieło w oparciu o „chęć unikania płacenia składek” jest absolutnie nieuprawnionym uogólnieniem.

\section{7.}

Należy podkreślić, że zarówno ZUS, jak i sądy powinny respektować zasadę swobody umów. Kształtując treść umowy, strony mają na względzie swój własny cel. Zawarcie umowy oznacza, że strony godzą się na określoną treść umowy, przy czym decydującego znaczenia nie ma nazwa umowy, ale jej treść (essentialia negotii).

Umowy cywilnoprawne - w tym i umowy o dzieło - wywołują nie tylko skutki cywilnoprawne, ale i w sferze prawa publicznego. Umowy są analizowane i oceniane głównie przez organy podatkowe (z podatkowego punktu widzenia) i ZUS. Jest oczywiste, na co wskazano już wyżej, że granica między usługami a dziełem bywa płynna ${ }^{14}$. ZUS, który (najczęściej po przeprowadzonej kontroli) stwierdza, że umowy, które wg płatnika składek są umowami o dzieło, są umowami o świadczenie usług, w znaczący sposób ingeruje w zasadę swobody umów. Nie ma wątpliwości tylko w sytuacjach, gdy strony zawierając umowę o świadczenie usług nazywają ją umową o dzieło. Jednakże ZUS wydając decyzję administracyjną, powinien w sposób niebudzący najmniejszych wątpliwości wyka-

14 Zob. np. wyrok SN z dnia 3 listopada 2000 r., IV CKN 152/00, LEX nr 45451; tak również: A. Brzozowski, Kodeks cywilny. Komentarz..., s. 411. 
zać, że pod pozorem umowy o dzieło strony de facto zawarły umowę o świadczenie usług. Nie jest dopuszczalne, aby ZUS „sądził”, „przypuszczał” etc. Sugerowany przez organ zamiar obejścia przepisów o charakterze publicznoprawnym musiałby być udowodniony, nie może być domniemywany. Gdyby tak rzeczywiście było, umowa byłaby bezwzględnie nieważna (zob. art. 58 k.c.).

W literaturze wskazuje się, że wprawdzie składki na ubezpieczenia społeczne nie są podatkiem, jednakże - zwłaszcza na płaszczyźnie ekonomicznej - mają bardzo podobny charakter do podatków. Z punktu widzenia płatnika składek podatki i składki na ubezpieczenia społeczne stanowią ten sam rodzaj uciążliwego, wysokiego kosztu prowadzenia działalności gospodarczej ${ }^{15}$. Skoro zatem w doktrynie prawa podatkowego wskazuje się na istnienie zasady in dubio pro tributario (w razie wątpliwości na korzyść podatnika) ${ }^{16}$, to zasadne jest jej przeniesienie na płaszczyznę „oskładkowania”.

Zastrzegając, że w zasadzie nie istnieje „problem odpowiedniego przycięcia krzewów”, gdyż przedmiot umowy mieści się w ramach konstrukcji umowy o dzieło, a nie umowy starannego działania, to SA powinien zważyć, że skoro powstał spór pomiędzy płatnikiem składek a ZUS, który SO rozstrzygnął na korzyść płatnika, to zmiana wyroku sądu I instancji i oddalenia odwołania powinno mieć miejsce tylko w sytuacji 100procentowej pewności, że rzeczywiście przycięcie krzewów do określonego kształtu nie może opierać się na umowie rezultatu. SA w błędnym uzasadnieniu nie przekonał, że tak jest.

8.

O ile w praktyce już nie dziwi profiskalne podejście ZUS, o tyle po orzeczeniach sądów można spodziewać się, że w razie jakichkolwiek wątpliwości będą rozstrzygały spory na korzyść płatnika składek, respektując

15 Zob. J. Wantoch-Rekowski, Składki na ubezpieczenia społeczne i ich charakter prawny [w:] A. Drwiłło (red.), Gdańskie Studia Prawnicze. Studia Prawno-Finansowe, Tom XVI, Gdańsk 2007, s. 249-258; J. Wantoch-Rekowski, Składki na ubezpieczenie emerytalne: konstrukcja i charakter prawny, Toruń 2005, s. 98-100.

16 Zob. np. B. Brzeziński, Wstęp do nauki prawa podatkowego, Toruń 2001, s. 146. 
zasadę swobody umów i zgodny zamiar stron, a dbałość o stan finansów ubezpieczeń społecznych i budżet państwa pozostawią władzy wykonawczej.

\section{Bibliografia:}

Brzeziński B., Wstęp do nauki prawa podatkowego, TNOiK, Toruń 2001.

Brzozowski A. [w:] K. Pietrzykowski (red.), Kodeks cywilny. Komentarz. Tom II, C.H. Beck, Warszawa 2011.

Kołakowski K., Komentarz do art. 627, [w:] G. Bieniek (red.), Komentarz do kodeksu cywilnego. Księga trzecia. Zobowiq̨zania, Tom 1, Warszawa 2011, Lexis.pl (elektr.).

Kozieł G. [w:] A. Kidyba (red.), Kodeks cywilny. Komentarz. Tom III. Zobowiqzania - część szczególna, Wolters Kluwer, Warszawa 2010.

Wantoch-Rekowski J., Składki na ubezpieczenie emerytalne: konstrukcja i charakter prawny, TNOiK, Toruń 2005.

Wantoch-Rekowski J., Składki na ubezpieczenia społeczne i ich charakter prawny [w:] A. Driwłło (red.), Gdańskie Studia Prawnicze. Studia Prawno-Finansowe, Tom XVI, Gdańsk 2007. 